\title{
PENGARUH MOTIVASI TERHADAP KINERJA DENGAN \\ KEPUASAN KERJA SEBAGAI VARIABEL MEDIASI DI \\ PT. TELKOM TELEKOMUNIKASI RIAU KEPULAUAN-BATAM
}

\author{
Adzhari Ramadhan \\ Program Magister Manajemen, Fakultas Ekonomi dan Bisnis, \\ Universitas Pembangunan Nasional "Veteran" Yogyakarta \\ adzhariramadhan01@gmail.com \\ Purbudi Wahyuni \\ Staf Pengajar Fakultas Ekonomi dan Bisnis Jurusan Manajemen \\ Universitas Pembangunan Nasional "Veteran" Yogyakarta \\ Purbudi.wahyuni@upnyk.ac.id
}

\begin{abstract}
In this research, a study conducted about how working motivation can influence someone works with the satisfaction aspect as the media. This research was intend to know the influence of working motivation to an employee performance, influence of work satisfaction to an employee performance and how intervening someone satisfaction of their works with influence of their work motivation will do to PT. Telkom Telekomunikasi Riau Kepulauan Batam workers works. The population on this research is based on all the workers in with the sum of 128 employees. The technic that used for this research is using purposive sampling, which means a technic to selectively choose a sample so the samples will define the whole population even only with 56 employee. Some of its employees are 43 people or 76,8\%, over 50 years old as many as 23 respondents or 41,1\%, S1 educated as many as 30 respondents or 53,6\% with 21-30 years working period there are 30 people or 53,6\%. Method used for data gathering is using a questionnaire form. The proposed hypothesis, will be tested statistically with structural equation modelling technic, with the help of SMATPL 3.2.7 program to tested the relation between these three variables. The research resulted with 1) Working motivation significantly influence working satisfaction, 2) Working satisfaction significantly influence employee performance, 3) Working motivations positively influence and significantly to employee work performance and work motivation positively influence and significantly to employee work performance with the media of employee working satisfaction in PT. Telkom Telekomuniasi Riau Kepulauan - Batam. This research implicated how PT. Telkom Telekomuniasi Riau Kepulauan - Batam management rise employee working performance by giving the employee motivation and satisfaction by working with them. The desire to controls and the satisfaction on having partners in works become the major issue that being the concern of management to boost up employee performance.
\end{abstract}

\begin{abstract}
ABSTRAK
Dalam penelitian ini, dilakukan penelitian tentang bagaimana motivasi kerja dapat memengaruhi seseorang bekerja dengan aspek kepuasan sebagai media. Penelitian ini bertujuan untuk mengetahui pengaruh motivasi kerja terhadap kinerja karyawan, pengaruh kepuasan kerja terhadap kinerja karyawan dan bagaimana mengintervensi kepuasan seseorang terhadap pekerjaannya dengan pengaruh motivasi kerja yang akan dilakukan terhadap PT. Telkom Telekomunikasi Riau Kepulauan - pekerja Batam bekerja. Populasi dalam penelitian ini didasarkan pada semua pekerja dengan jumlah 128 karyawan. Teknik
\end{abstract}


yang digunakan untuk penelitian ini adalah menggunakan purposive sampling, yang berarti teknik untuk memilih sampel secara selektif sehingga sampel akan menentukan seluruh populasi bahkan hanya dengan 56 karyawan. Beberapa karyawannya adalah 43 orang atau $76,8 \%$, lebih dari 50 tahun sebanyak 23 responden atau 41,1\%, berpendidikan S1 sebanyak 30 responden atau 53,6\% dengan masa kerja 21-30 tahun ada 30 orang atau 53,6\%. Metode yang digunakan untuk pengumpulan data adalah menggunakan formulir kuesioner. Hipotesis yang diajukan, akan diuji secara statistik dengan teknik pemodelan persamaan struktural, dengan bantuan program SMATPL 3.2.7 untuk menguji hubungan antara ketiga variabel ini. Penelitian ini menghasilkan 1) Motivasi kerja berpengaruh signifikan terhadap kepuasan kerja, 2) Kepuasan kerja berpengaruh signifikan terhadap kinerja karyawan, 3) Motivasi kerja berpengaruh positif dan signifikan terhadap kinerja karyawan dan motivasi kerja berpengaruh positif dan signifikan terhadap kinerja kerja karyawan dengan media karyawan. kepuasan kerja di PT. Telkom Telekomuniasi Kepulauan Riau - Batam. Penelitian ini melibatkan bagaimana PT. Telkom Telekomuniasi Riau Kepulauan - Batam manajemen meningkatkan kinerja karyawan dengan memberikan motivasi dan kepuasan karyawan dengan bekerja dengan mereka. Keinginan untuk mengontrol dan kepuasan memiliki mitra dalam pekerjaan menjadi masalah utama yang menjadi perhatian manajemen untuk meningkatkan kinerja karyawan

Kata Kunci : motivasi kerja, kepuasan kerja, kinerja karyawan

\section{PENDAHULUAN}

Di era globalisasi saat ini, dengan tingkat persaingan bisnis yang semakin ketat diperlukan beberapa cara agar perusahaan dapat mempertahankan dalam penguasaan pasarnya. Salah satu strategi yang paling tepat adalah meningkatkan kualitas sumber daya manusia yang sangat berperan dalam menentukan nasib perusahaan tersebut. Dalam hal ini diperlukan pengembangan sumber daya manusia yang baik dan benar agar kesuksesan perusahaan dapat tercapai. Wardhana (2014) mengatakan bahwa Pengembangan sumber daya manusia adalah fungsi sumber daya manusia yang utama dan tidak hanya terdiri atas pelatihan dan pengembangan namun juga aktivitasaktivitas perencanaan dan pengembangan karir individu, pengembangan organisasi, serta manajemen dan penilaian kinerja. Karyawan merupakan sumber daya yang penting bagi perusahaan, karena memiliki bakat, tenaga dan kreativitas yang sangat dibutuhkan oleh perusahaan untuk mencapai tujuannya. Sebaliknya, sumber daya manusia juga mempunyai berbagai macam kebutuhan yang ingin dipenuhinya.
Keinginan untuk memenuhi kebutuhan inilah yang dipandang sebagai pendorong atau penggerak bagi seseorang untuk melakukan sesuatu, termasuk melakukan pekerjaan atau bekerja.

Menurut Robbins (2006) faktor-faktor yang digunakan untuk meningkatkan kinerja karyawan diantaranya motivasi dan kepuasan. Kinerja karyawan yang merupakan hasil olah pikir dan tenaga dari seorang karyawan terhadap pekerjaan yang dilakukannya, dapat berwujud, dilihat, dihitung jumlahnya, akan tetapi dalam banyak hal hasil olah pikiran dan tenaga tidak dapat dihitung dan dilihat, seperti ideide pemecahan suatu persoalan, inovasi baru suatu produk barang atau jasa, bisa juga merupakan penemuan atas prosedur kerja yang lebih efisien. Sumber daya manusia merupakan aset penting dalam suatu organisasi, karena merupakan sumber yang mengendalikan perusahaan serta mempertahankan dan mengembangkan perusahaan dalam menghadapi berbagai tuntutan zaman, oleh karena itu sumber daya manusia harus diperhatikan, dijaga 
dan dikembangkan (Wibowo dan Susilowati, 2010).

Penelitian ini dilakukan di PT. Telkom Kantor Wilayah Telekomunikasi Riau Kepulauan - Batam yang merupakan BUMN yang bergerak dibidang jasa layanan telekomunikasi dan jaringan di wilayah Indonesia. Ada beberapa permasalahan yang masih dirasakan pada perusahaan ini terkait dengan kinerja karyawan. Menurut data penilaian kinerja tahun 2013-2015 memberikan informasi rata-rata kinerja karyawan berada pada kategori P3 (Baik), sedangkan pada penilaian tahun 2016 rata-rata nilai kinerja karyawan meningkat pada kategori P2 (Baik sekali) dan kembali menurun pada tahun 2017 pada peringkat P3 (Baik). Hal ini menunjukkan bahwa masih terjadi fluktuasi kinerja pada PT. Telkom, yang diduga karena belum optimalnya motivasi dan kepuasan kerja.

Robbins (2006) mengatakan bahwa karyawan yang mendapatkan kepuasan kerja biasanya berprestasi kerja lebih baik dari pada karyawan yang tidak memperoleh kepuasan kerja. karyawan akan merasa puas atas kerja yang telah atau sedang dijalankan, apabila apa yang dikerjakan itu dianggapnya telah memenuhi harapannya, sesuai dengan tujuan ia bekerja. Apabila seorang karyawan mendambakan sesuatu, maka ia memiliki suatu harapan, dengan demikian ia akan termotivasi untuk melakukan tindakan ke arah pencapaian harapan tersebut, jika harapannya terpenuhi, maka ia akan merasa puas. Pada kondisi ini karyawan yang mendapatkan kepuasan kerja yang tinggi, diharapkan mempunyai kinerja yang tinggi pula.

Selain kepuasan kerja, perusahaan juga harus memperhatikan mengenai bagaimana menjaga dan mengelola motivasi karyawan dalam bekerja agar selalu tinggi dan fokus pada tujuan perusahaan. Menjaga motivasi karyawan itu sangatlah penting karena motivasi itu adalah motor penggerak bagi setiap individu yang mendasari mereka untuk bertindak dan melakukan sesuatu.
Orang tidak akan melakukan sesuatu hal secara optimal apabila tidak mempunyai motivasi yang tinggi dari dalam dirinya sendiri untuk melalukan hal tersebut. Menurut Inayatullah, Atiya dan Jehangir Palwasha (2013) motivasi adalah kekuatan atau energi seseorang yang dapat menimbulkan tingkat persistensi dan antusiasme dalam melaksanakan suatu kegiatan, baik yang bersumber dari dalam diri sendiri (motivasi instriksik) maupun dari luar individu (motivasi ekstrinsik). Motivasi dapat berasal dari dalam diri maupun luar diri seseorang, sebagai contoh motivasi intrinsik jika seseorang berhasil mencapai motivasinya, maka yang bersangkutan cenderung untuk terus termotivasi. Sebaliknya jika seseorang sering gagal mewujudkan motivasinya, maka yang bersangkutan mungkin tetap terus bekerja sampai motivasinya tercapai atau menjadi putus asa yang berakibat langsung kepada kinerja kerja dari karyawan tersebut, sedangkan motivasi ekstrinsik merupakan faktor eksternal diluar karyawan yang dapat mempengaruhi motivasi karyawan.

Penelitian tentang pengaruh motivasi kerja terhadap kinerja karyawan dengan kepuasan kerja sebagai variabel mediasi, telah banyak dilakukan diantaranya Miao (2007), yang menunjukkan bahwa motivasi intrinsik dan ekstrinsik memiliki pengaruh yang positif dan signifikan terhadap kinerja perilaku dan kinerja hasil. Sementara Jehanzeb (2012), menunjukkan bahwa motivasi berpengaruh positif dan signifikan terhadap kepuasan kerja. Hal ini menunjukkan bahwa motivasi tidak hanya berpengaruh terhadap kinerja seperti pada penelitian sebelumnya, tetapi motivasi juga dapat berpengaruh terhadap kepuasan kerja. Hasil penelitian Khan (2011) dan Tentama (2015), menunjukkan adanya hubungan yang positif dan signifikan antara kepuasan kerja dan kinerja. Kepuasan kerja yang terpenuhi baik intrinsik atau ekstrinsik akan membuat karyawan lebih termotivasi 
meningkatkan kinerjanya. Berdasarkan hal tersebut juga dapat diketahui bahwa kepuasan kerja secara tidak langsung dapat meningkatkan motivasi karyawan yang berdampak pada peningkatan kinerja. Sementara Nitasari (2012), dari hasil penelitiannya mengemukakan bahwa motivasi berpengaruh terhadap kinerja dengan dimediasi oleh kepuasan kerja. Hal ini mengartikan bahwa ketika dalam diri seorang karyawan memiliki motivasi yang tinggi terhadap pekerjaannya maka akan langsung mempengaruhi peningkatan kinerja karyawan tersebut dan adapula motivasi karyawan tersebut mempengaruhi kepuasan kerja terlebih dahulu yang kemudian dengan adanya kepuasan kerja yang timbul dari karyawan maka akan mempengaruhi kinerja karyawan seharihari. Hal ini menunjukkan bahwa kepuasan kerja juga dapat dicapai dengan adanya motivasi yang baik dalam diri karyawan.

Berdasarkan uraian di atas, maka penelitian tertarik untuk menganalisis apakah motivasi kerja berpengaruh terhadap kepuasan dan kinerja karyawan, apakah kepuasan kerja berpengaruh terhadap kinerja karyawan dan apakah kepuasan kerja sebagai variabel intervening pengaruh motivasi terhadap kinerja karyawan PT. Telkom Kantor Wilayah Telekomuniasi Riau Kepulauan - Batam.

\section{Konsep Kinerja Karyawan}

Pengertian kinerja merupakan gambaran mengenai tingkat pencapaian pelaksanaan suatu program kegiatan atau kebijakan dalam mewujudkan sasaran, tujuan, visi dan misi organisasi yang dituangkan melalui perencanaan strategis suatu organisasi (Moeheriono, 2010).Sedangkan menurut Dessler (2000), kinerja merupakan prestasi kerja, yaitu perbandingan antara hasil kerja yang secara nyata dengan standar kerja yang ditetapkan. Pendapat lain yang disampaikan oleh Mathis (2011) terdapat tiga faktor utama yang dapat mempengaruhi bagaimana individu atau seorang karyawan dalam bekerja, yaitu: (1) kemampuan individual untuk melakukan pekerjaan tersebut, (2) tingkat usaha yang dicurahkan, dan (3) dukungan organisasi. Kinerja individual ditingkatkan sampai tingkat dimana ketiga komponen tersebut ada dalam diri karyawan. Akan tetapi, kinerja berkurang apabila salah satu indikator ini dikurangi atau tidak ada.

Penilaian kinerja sangat penting karena menjadi acuan bagi karyawan di dalam penetapan insentif, gaji dasar serta juga di dalam kenaikan jabatan serta golongan. Secara khusus SKI dilakukan pada awal tahun, karyawan dituntut untuk merencanakan program-program kerja yang akan dilakukan untuk mendukung target perusahaan yang telah ditetapkan sebelumnya. Di dalam aturan yang ditentukan proses ini dilakukan secara negosiasi antara atasan dan juga bawahan. Jika sudah setujui maka akan disusun secara resmi dan di tandatangani oleh atasan karyawan. SKI yang digunakan untuk menilai kinerja para karyawan selama satu tahun. SKI ini akan digunakan untuk menilai kinerja karyawan menurut target dan juga realisasinya. Penilaian performansi (SKI) sangat penting karena ini menunjukkan tingkat keberhasilan karyawan selama setahun penuh, dan juga SKI juga menjadi dasar atasan untuk memberikan insentif bagi karyawan.

Sistem penilaian kinerja PT. Telkom dengan Penilaian Berdasarkan Performance disebut Sasaran Kinerja Individu (SKI), sesuai Peraturan Perusahaan No. PR.208.01/R.01/PS730/COP-

J2000000/2014. Adapun indikatornya meliputi:

1. Hasil kerja, yaitu kuantitas dan kualitas kinerja yang berhasil dicapai oleh karyawan sesuai dengan target atau sasaran kerja individu dalam jabatannya.

2. Kepemimpinan, yaitu kemampuan karyawan untuk membuat keputusan dan mendorong atau menggerakkan 


\section{Buletin Ekonomi}

bawahan menuju pencapaian tujuan unit kerja.

3. Keterampilan kerja, yaitu pengetahuan dan kemahiran karyawan untuk melaksanakan tugas-tugas praktis yang menggunakan peralatan, manual, dan atau teknis administratif tertentu.

4. Kerjasama, yaitu kesediaan karyawan untuk mengadakan hubungan kerja dan bekerjasama dengan pihak lain dalam rangka menyelesaikan tugas-tugas jabatannya.

5. Disiplin, yaitu kesediaan dan upaya karyawan untuk teratur dalam bekerja agar segala sesuatu berjalan lancar dan tertib.

6. Inisiatif, yaitu kesediaan dan kemampuan memberikan gagasan baru diluar rutinitasatau berupa pilihan tindakan yang cepat dan tepat pada situasi yang tepat.

7. Peningkatan tanggung jawab, yaitu kesediaan dan kemampuan karyawan untuk menyelesaikan tugas dan tanggung jawab yang lebih berat dari pada yang biasa dilaksanakannya sehari-hari.

\section{Konsep Motivasi Kerja}

Menurut Robbins dalam Donni Junni Priansa (2014) Motivasi kerja sebagai kesediaan untuk melaksanakan upaya tingkat tinggi untuk mencapai tujuan-tujuan keorganisasian yang dikondisikan oleh kemampuan upaya untuk memenuhi kebutuhan individual tertentu.

Dimensi dan indikator dari teori motivasi McClelland dalam Hasibuan (2009), hal-hal yang memotivasi seorang karyawan adalah:

1. Kebutuhan akan prestasi (Need for achievement)

Kebutuhan akan prestasi merupakan daya penggerak yang memotivasi semangat bekerja seseorang. Oleh karena itu kebutuhan akan prestasi akan mendorong seseorang untuk mengembangkan kreativitas dan mengerahkan semua kemampuan serta energi yang dimilikinya demi mencapai prestasi kerja yang maksimal. Seseorang menyadari bahwa hanya dengan mencapai prestasi kerja yang tinggi akan dapat memperoleh pendapatan yang besar.

2. Kebutuhan akan afiliasi (Need for affiliation)

Kebutuhan akan afiliasi menjadi daya penggerak yang akan memotivasi semangat bekerja seseorang. Oleh karena itu kebutuhan akan afiliasi ini yang akan merangsang gairah bekerja karyawan karena setiap orang menginginkan seperti kebutuhan akan perasaan diterima oleh orang lain di lingkungan ia tinggal dan bekerja (sense of belonging), kebutuhan akan perasaan dihormati, karena setiap manusia merasa dirinya penting (sense of importance), kebutuhan akan perasaan maju dan tidak gagal (sense of achievement), dan kebutuhan akan perasaan ikut serta (sense of participation).

3. Kebutuhan akan kekuasaan (Need for power)

Kebutuhan akan kekuasaan merupakan daya penggerak yang memotivasi semangat kerja karyawan. Kebutuhan akan kekuasaan akan merangsang dan memotivasi gairah kerja serta mengerahkan semua kemampuannya demi mencapai kekuasaan atau kedudukan yang terbaik. Ego manusia yang ingin lebih berkuasa dari manusia lainnya akan menimbulkan persaingan. Persaingan ditumbuhkan secara sehat oleh manajer dalam memotivasi bawahannya, supaya mereka termotivasi untuk bekerja giat.

Motivasi yang tinggi yang ada pada diri karyawan merupakan modal bagi suatu perusahaan untuk dapat mewujudkan kepuasan kerja yang tinggi pula, hal ini tentunya merupakan harapan yang ingin dicapai oleh perusahaan. Menurut Rivai (2008) mengatakan bahwa hubungan 
motivasi terhadap kepuasan kerja adalah apabila individu termotivasi, mereka akan membuat pilihan yang positif untuk melakukan sesuatu, karena dapat memuaskan keinginan mereka. Karyawan merupakan pelaku yang menunjang tercapainya tujuan. Untuk mengembangkan sikap-sikap positif yang akan mengarahkan karyawan pada pencapaian tujuan perusahaan, maka motivasi harus ditingkatkan, dalam hal ini baik motivasi eksternal maupun motivasi internal.

Motivasi merupakan dorongan, upaya dan keinginan yang ada pada diri manusia yang akan mengarahkan perilaku untuk melakukan tugas atau pekerjaan dengan baik, sedangkan kepuasan merupakan sikap yang menunjukkan adanya kesesuaian antara harapan dan hasil yang didapatkan. Berdasarkan uraian diatas dapat disimpulkan bahwa hipotesis kedua dalam penelitian ini adalah motivasi berpengaruh terhadap kepuasan kerja.

Organisasi yang dihadapkan dengan berbagai tantangan inovasi dan kreatifitas, pengadopsian strategi yang dilakukan sebaiknya tidak hanya untuk meningkatkan motivasi eksternal karyawan saja. Tantangan kompetitif yang harus dihadapi, membutuhkan karyawan yang juga memiliki motivasi instrinsik dalam melakukan tugas-tugas mereka. Hal ini didasari oleh hasil penelitian yang menunjukkan bahwa motivasi instrinsik dan ekstrinsik dapat memaksimalkan kinerja (Yousaf, 2015). Cara yang dapat digunakan untuk memantau kinerja karyawan adalah kinerja appraisal yaitu penilaian kinerja yang dapat memantau kualitas kinerja karyawan melalui sistim manajemen kinerja yang dihubungkan dengan tujuan organisasi, kinerja hari demi hari, pengembangan professional serta hadiah dan insentif. Dengan kata sederhana bahwa penilaian yang dilakukan adalah penilaian kinerja dan perubahan perilaku individu dalam organisasi secara sistimatis yang terbentuk karena adanya dorongan motivasi (Zameer, 2014).
Hasil penelitian Ali (2012), menunjukkan bahwa faktor motivasi memiliki pengaruh pada proses kerja karyawan. Berdasarkan uraian diatas dapat disimpulkan bahwa hipotesis pertama dalam penelitian ini adalah motivasi kerja berpengaruh terhadap kinerja karyawan. Berdasarkan penjelasan tersebut maka hipotesis ketiga penelitian ini adalah:

H1 : Motivasi kerja berpengaruh terhadap kinerja karyawan di PT. Telkom Kantor Wilayah Telekomuniasi Riau Kepulauan - Batam.

\section{Konsep Kepuasan Kerja}

Kepuasan kerja menunjukkan kesesuaian antara harapan seseorang yang timbul dan imbalan yang disediakan pekerjaan, sehingga kepuasan kerja juga berkaitan erat dengan teori keadilan, perjanjian psikologis dan motivasi (Robbins dan Judge, 2008). Adapun indikator untuk mengukur kepuasan kerja menurut Luthans (2009) adalah 1) Kepuasan terhadap Gaji, 2) Kepuasan terhadap Promosi, 3) Kepuasan terhadap Rekan kerja, 4) Kepuasan terhadap Pengawasan dan 5) Kepuasan terhadap Pekerjaan itu sendiri.

Menurut Robbins (2006), kepuasan kerja adalah cara pekerja merasakan mengenai pekerjaaanya. Kepuasan kerja dipengaruhi oleh beberapa aspek pekerjaan, meliputi: upah/gaji. kondisi kerja, pengawasan, teman kerja, materi pekerjaan, jaminan kerja, serta kesempatan untuk maju. Kepuasan kerja merupakan suatu sikap yang positif yang menyangkut penyesuaian diri yang sehat dari para karyawan terhadap kondisi dan situasi kerja, termasuk didalamnya masalah upah, kondisi sosial, kondisi fisik dan kondisi psikologis.

Semakin banyak aspek dalam pekerjaannya yang sesuai dengan keinginan dan sistem nilai yang dianut individu, semakin tinggi tingkat kepuasan yang didapat. Kurang terpenuhinya kepuasan kerja akan menimbulkan penurunan produktivitas karyawan, sehingga 
pemberian kebutuhan yang bersifat material dan non material perlu diberikan untuk tercapainya kepuasan kerja. Hasil penelitian Khan (2011), menjelaskan adanya pengaruh yang signifikan antara kepuasan kerja dan kinerja. Berdasarkan uraian diatas dapat disimpulkan bahwa hipotesis ketiga dalam penelitian ini adalah kepuasan kerja berpengaruh terhadap kinerja. Berdasarkan penjelasan tersebut maka hipotesis kedua penelitian ini adalah sebagai berikut:

$\mathrm{H} 2$ : Kepuasan kerja berpengaruh terhadap kinerja karyawan di PT. Telkom Kantor Wilayah Telekomuniasi Riau Kepulauan - Batam.

Variabel intervening sering disebut variabel mediasi atau variabel proses. Hipotesis yang berkaitan dengan mediasi sangat umum dijumpai dalam penelitian keperilakuan. Intervening terjadi jika variabel independen mempengaruhi variabel dependen secara tidak langsung melalui paling tidak satu variabel mediator. Bila terdiri dari hanya satu mediator maka disebut simple mediation dan bila proses mediasi melibatkan lebih dari satu mediator maka disebut multiple mediation (Baron dan Kenny, 1986).

Motivasi yang dimiliki oleh seorang karyawan dalam suatu perusahaan terbukti dapat mempengaruhi kinerjanya. Motivasi mempengaruhi kinerja melalui berbagai

\section{METODE}

Populasi dalam penelitian ini adalah seluruh karyawan atau staf yang bekerja di PT. Telkom Kantor Wilayah Telekomunikasi Riau Kepulauan - Batam yang berjumlah 128 orang. Sedangkan teknik pengambilan sampel menggunakan metode purposive samplingyaitu teknik untuk menentukan sampel penelitian dengan beberapa pertimbangan tertentu yang bertujuan agar data yang diperoleh nantinya bisa lebih representatif. Dalam penelitian ini jumlah sampel adalah sebanyak 56 responden.

Data dalam penelitian ini menggunakan data primer. Data Primer mekanisme termasuk didalamnya melalui mekanisme intervening. Kepuasan kerja telah terbukti memiliki peran intervening dalam hubungan antara motivasi terhadap kinerja (Nitasari, 2012). Dengan demikian hipotesis keempat dalam penelitian ini adalah kepuasan kerja memiliki peran intervening dalam pengaruh motivasi terhadap kinerja karyawan.Berdasarkan pendapat tersebut maka hipotesis keempat penelitian ini adalah sebagai berikut:

H3: Pengaruh Motivasi Terhadap Kinerja Karyawan Dengan Kepuasan Kerja Sebagai Variabel Intervening Pada PT. Telkom Kantor Wilayah Telekomuniasi Riau Kepulauan Batam.

\section{Kerangka Penelitian}

Kerangka penelitian ini dapat digambarkan sebagai berikut:

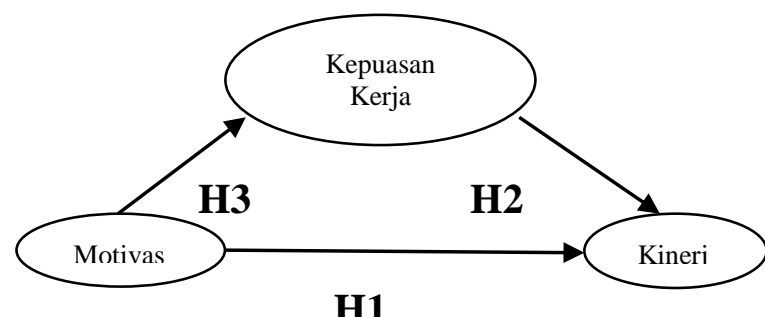

H1

Gambar 1. Kerangka Pemikiran Teoritis

merupakan informasi yang dikumpulkan peneliti langsung dari sumbernya. Data Primer pada penelitian ini diperoleh dengan cara membuat dan menyebarkan kuesioner kepada responden.

Variabel pelitian ini terdiri dari variabel independen, variabel dependen dan variabel medias. Variabel independentl variabel bebas dalam penelitian ini adalah motivasi kerja yang diukur menggunakan 6 item pertanyaan yang mengacu pada teori kebutuhan Mc. Clelland. Variabel mediasi yaitu variabel penyela/ antara yang terletak diantara variabel independen dan dependen, 
sehingga variabel independen tidak langsung mempengaruhi berubahnya atau timbulnya variabel dependen (Sugiyono, 2013). Variabel mediasi dalam penelitian ini adalah kepuasan kerja yang diukur dengan 10 item pertanyaan mengacu pada teori indikator yang dikemukakan Luthans, (2009). Sedangkan variabel dependen adalah kinerja karyawan yang diukur dengan 16butir pernyataan berdasarkan Performance disebut Sasaran Kinerja Individu (SKI), sesuai Peraturan Perusahaan

No.

\section{ANALISIS DAN PEMBAHASAN}

Convergent validity dilakukan dengan membandingkan nilai outer model (loading factor) dengan nilai kritis 0,5. Jika loading faktor > 0,5 maka butir instrumen dinyatakan valid dan sebaliknya jika nilainya $<0,5$ maka dinyatakan gugur. Hasil covergent validity dapat ditunjukkan pada Tabel berikut:

Tabel 1. Convergent Validity

\begin{tabular}{lccc}
\hline \multicolumn{1}{c}{ Variabel } & Outer Loading & Nilai Kritis & Keterangan \\
\hline Motivasi Kerja & $0,869 \mathrm{~s} / \mathrm{d} 0,935$ & 0,5 & Valid \\
Kepuasan & $0,851 \mathrm{~s} / \mathrm{d} 0,937$ & 0,5 & Valid \\
Kerja & $0,800 \mathrm{~s} / \mathrm{d} 0,932$ & 0,5 & Valid \\
Kinerja &
\end{tabular}

Sumber: Data primer diolah, 2019

Berdasarkan hasil pengujian validitas seperti pada Tabel 4.5 menunjukkan bahwa hasil validitas telah memenuhi convergent validity karena semua loading factor $\geq 0,5$. Selain itu dari hasil uji signifikansi dengan uji $t$, menunjukkan bahwa seluruh nilai $\mathrm{p}<0,05$. Dengan demikian, seluruh indikator dapat dinyatakan valid.

Setelah dilakukan covergent validitytahap pengujian validitas berikutnya adalah Discriminant Validity yaitu analisis untuk mengetahui validitas konstruk dengan cara menilai Akar AVE (Average Variance Extracted), dengan membandingkan korelasi antar konstruk dengan konstruk lainnya, dan hasilnya ditunjukkan pada Tabel 2.

Tabel 2. Discriminant Validity
PR.208.01/R.01/PS730/COPJ2000000/2014.

Sebelum dilakukan analisis data terlebih dahulu dilakukan uji validitas dan reliabilitas. Hasil uji validitas menunjukkan bahwa seluruh butir pertanyaan dapat dinyatakan valid, dan hasil reliabilitas menemukan seluruh variabel dapat dinyatakan reliabel. Teknik analisis data dalam penelitian ini menggunakan analisis Structural Equation Modelling dengan Program SMART PLS 3.2.7.

\begin{tabular}{lccccc}
\hline & $\begin{array}{c}\text { Kepuasan } \\
\text { Kerja }\end{array}$ & $\begin{array}{c}\text { Kinerja } \\
\text { Karyawan }\end{array}$ & $\begin{array}{c}\text { Motivasi } \\
\text { Kerja }\end{array}$ & AVE & $\sqrt{ }$ AVE \\
\hline $\begin{array}{l}\text { Kepuasan } \\
\text { Kerja }\end{array}$ & 1.000 & & & 0.806 & 0.898 \\
$\begin{array}{l}\text { Kinerja } \\
\text { Karyawan }\end{array}$ & 0.565 & 1.000 & & 0.759 & 0.871 \\
$\begin{array}{l}\text { Motivasi } \\
\text { Kerja }\end{array}$ & 0.460 & 0.603 & 1.000 & 0.822 & 0.907 \\
\hline
\end{tabular}

Sumber: Data primer diolah, 2019

Berdasarkan tabel diatas dapat disimpulkan bahwa akar AVE pada seluruh Konstruk lebih tinggi daripada korelasi antara variabel tersebut dengan variabel lainnya, sehingga dapat dinyatakan valid secara diskriminan.

Sedangkan untuk pengujian reliabilitas menggunakan composite reliability. Apabila suatu konstruk yang mempunyai nilai composite reliability besarnya diatas 0,70 maka konstruk dinyatakan reliable. Hasil uji reliabilitas pertanyaan tentang variabel motivasi kerja, kepuasan kerja dan kinerja karyawan, dapat diringkas sebagaimana yang tersaji dalam Tabel 3 berikut ini.

\section{Tabel 3. Hasil Pengujian Reliabilitas}

\begin{tabular}{lccc}
\hline \multicolumn{1}{c}{ Variabel } & $\begin{array}{c}\text { Composite } \\
\text { Reliability }\end{array}$ & $\begin{array}{c}\text { Nilai } \\
\text { Kritis }\end{array}$ & Keterangan \\
\hline Kepuasan Kerja & 0.976 & 0,7 & Reliabilitas Baik \\
Kinerja Karyawan & 0.981 & 0,7 & Reliabilitas Baik \\
Motivasi Kerja & 0.965 & 0,7 & Reliabilitas Baik \\
\hline
\end{tabular}

Sumber: Data primer diolah, 2019

Berdasarkan ringkasan hasil uji reliabilitas seperti yang terangkum dalam Tabel 3, dapat diketahui bahwa nilai koefisien composite reability untuk ketiga variabel motivasi kerja, kepuasan kerja 
dan kinerja karyawan lebih besar dari 0,7. Dengan mengacu pada teori diatas maka semua butir pertanyaan dalam variabel penelitian adalah handal. Sehingga butirbutir pertanyaan dalam variabel penelitian dapat digunakan untuk penelitian selanjutnya.

\section{Pengujian Hipotesis dengan} SMARTPLS 3.2.7

Analisis kuantitatif yang digunakan dalam penelitian ini adalah analisis jalur atau Path Analisys. Model analisis jalur ini digunakan analisis SMART PLS 3.2.7. Analisis ini dipilih untuk mengetahui pengaruh secara bertahap motivasi kerja terhadap kinerja karyawan melalui kepuasan kerja. Hasil analisis SMART PLS 3.0 dapat ditunjukkan pada Tabel 4.

Tabel 4. Pengaruh Langsung Antar Variabel

\begin{tabular}{lcccc}
\hline & $\begin{array}{c}\text { Original } \\
\text { Sample } \\
(\mathbf{O})\end{array}$ & $\begin{array}{c}\text { T Statistics } \\
(\mid \mathbf{O} / \text { STDEV } \mid)\end{array}$ & $\begin{array}{c}\mathbf{P} \\
\text { Values }\end{array}$ & Keterangan \\
\hline $\begin{array}{l}\text { Motivasi } \\
\text { Kerja }->\end{array}$ & & & & \\
$\begin{array}{l}\text { Kepuasan } \\
\text { Kerja } \rightarrow\end{array}$ & 0.168 & 2.191 & 0.029 & H4 didukung \\
Kinerja & & & & \\
Karyawan & & & & \\
\hline
\end{tabular}

Sumber: Data primer diolah, 2019

\section{Tabel 5. Pengaruh Tidak Langsung} Antar Konstruk

\begin{tabular}{lcccc}
\hline & $\begin{array}{c}\text { Original } \\
\text { Sample } \\
(\mathbf{O})\end{array}$ & $\begin{array}{c}\text { T Statistics } \\
(\mid \mathbf{O} / \mathbf{S T D E V})\end{array}$ & $\begin{array}{c}\mathbf{P} \\
\text { Values }\end{array}$ & Keterangan \\
\hline $\begin{array}{l}\text { Motivasi } \\
\text { Kerja -> } \\
\text { Kinerja } \\
\text { Karyawan }\end{array}$ & 0.435 & 3.039 & 0.003 & H1 didukung \\
$\begin{array}{l}\text { Kepuasan } \\
\text { Kerja }> \\
\text { Kinerja } \\
\text { Karyawan }\end{array}$ & 0.365 & 2.547 & 0.011 & H2 didukung \\
$\begin{array}{l}\text { Motivasi } \\
\text { Kerja -> } \\
\text { Kepuasan } \\
\text { Kerja }\end{array}$ & 0.460 & 4.209 & 0.000 & H3 didukung \\
\hline
\end{tabular}

Sumber: Data primer diolah, 2019

Hasil analisis jalur motivasi kerja terhadap kinerja dengan kepuasan kerja sebagai intervening ditujukan pada gambar 2 sebagai berikut.

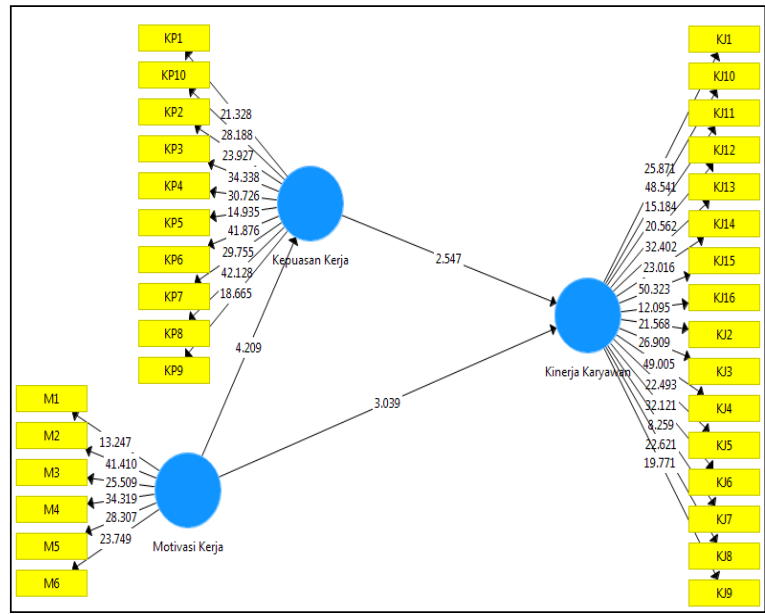

\section{Gambar 2. Hasil Analisis Jalur}

\section{Pembahasan dan Diskusi}

\section{Pengaruh Motivasi Kerja Terhadap} Kinerja Karyawan

Hasil pengujian dengan PLS membuktikan bahwa motivasi kerja berpengaruh signifikan terhadap Kinerja karyawan PT. Telkom Kantor Wilayah Telekomuniasi Riau Kepulauan - Batam (H3diterima). Hal ini dapat dilihat pada koefesien path motivasi kerja terhadap kinerja karyawan sebesar 0,435 $(\mathrm{p}=0,003<0,05)$ yang menunjukkan adanya pengaruh positif. Ini menunjukkan bahwa motivasi kerja karyawan PT. Telkom Kantor Wilayah Telekomuniasi Riau Kepulauan - Batam mampu meningkatkan kinerja karyawannya. Motivasi kerja yang berkaitan dengan kebutuhan prestasi, kebutuhan kekuasaan dan kebutuhan afiliasi akan meningkatkan kinerjanya. Dengan demikian hipotesis ketiga penelitian ini yang menyatakan "H1: Motivasi kerja berpengaruh terhadap kinerja karyawan di PT. Telkom Kantor Wilayah Telekomuniasi Riau Kepulauan - Batam" dapat didukung.

Hal ini didasari oleh hasil penelitian yang menunjukkan bahwa motivasi instrinsik dan ekstrinsik dapat memaksimalkan kinerja (Yousaf, 2015). Cara yang dapat digunakan untuk memantau kinerja karyawan adalah kinerja appraisal yaitu penilaian kinerja yang dapat memantau kualitas kinerja karyawan 
melalui sistim manajemen kinerja yang dihubungkan dengan tujuan organisasi, kinerja hari demi hari, pengembangan professional serta hadiah dan insentif. Dengan kata sederhana bahwa penilaian yang dilakukan adalah penilaian kinerja dan perubahan perilaku individu dalam organisasi secara sistimatis yang terbentuk karena adanya dorongan motivasi (Zameer, 2014).

Hal ini dapat diartikan bahwa motivasi merupakan faktor yang memberikan dorongan sangat penting terhadap peningkatan kinerja karyawan. Bekerja di PT. Telkom Kantor Wilayah Telekomuniasi Riau Kepulauan - Batam yang dalam keadaan tuntutan kerja yang besar di lingkungan karyawan BUMN, memang sangat dibutuhkan motivasi kerja karyawan. Karyawan yang memiliki motivasi tinggi tentunya akan memiliki kebutuhan yang besar baik kebutuhan untuk prestasi, kekuasaan dan afiliasi. Hal ini tentunya mendorong karyawan untuk bekerja lebih giat lagi guna memenuhi kebutuhan-kebutuhan tersebut.

Karyawan yang memiliki motivasi yang tinggi berarti karyawan akan berusaha keras untuk memenuhi kebutuhan karyawan yang terdiri dari kebutuhan akan prestasi, kekuasaan dan afiliasi. Kebutuhan untuk berprestasi yang merupakan refleksi dari dorongan akan tanggung jawab untuk pemecahan masalah. Seorang karyawan yang mempunyai kebutuhan akan berprestasi tinggi cenderung untuk berani mengambil resiko. Kebutuhan untuk berprestasi adalah kebutuhan untuk melakukan pekerjaan lebih baik dari pada sebelumnya, selalu berkeinginan mencapai prestasi yang lebih tinggi, sehingga akan cenderung meningkatkan kinerjanya.

Hasil penelitian ini memperkuat hasil penelitian yang dilakukan oleh penelitian Ali (2012), menunjukkan bahwa faktor motivasi memiliki pengaruh pada proses kerja karyawan. Hasil penelitian juga mendukung penelitian Brahmasari dan
Suprayetno (2008), dan penelitian Prabowo dkk (2017)yang secara konsisten menemukan hasil yang sama yaitu motivasi kerja berpengaruh positif dan signifikan terhadap kinerja karyawan. Motivasi adalah alat tambahan bernilai bagi kinerja organisasi. Dalam era persaingan dan globalisasi, maka perlu membuat titik perhatian terhadap motivasi karyawan dan kepuasan kerja untuk mencapai pertumbuhan dan keberhasilan.

\section{Pengaruh Kepuasan Kerja} Terhadap Kinerja Karyawan

Hasil pengujian dengan PLS membuktikan bahwa kepuasan kerja berpengaruh signifikan terhadap kinerja karyawan PT. Telkom Kantor Wilayah Telekomuniasi Riau Kepulauan - Batam (H2 diterima). Hal ini dapat dilihat pada koefesien path kepuasan kerja terhadap kinerja karyawan sebesar 0,365 $(\mathrm{p}=0,011<0,05)$ yang menunjukkan adanya pengaruh positif. Ini menunjukkan bahwa kepuasan kerja karyawan PT. Telkom Kantor Wilayah Telekomuniasi Riau Kepulauan - Batam mampu meningkatkan kinerjanya. Karyawan yang lebih puas akan cenderung memiliki kinerja yang lebih baik dibandingkan dengan karyawan yang tidak puas dalam bekerja. Dengan demikian hipotesis kedua penelitian ini yang menyatakan "H2: Kepuasan kerja berpengaruh terhadap kinerja karyawan di PT. Telkom Kantor Wilayah Telekomuniasi Riau Kepulauan - Batam" dapat didukung.

Menurut Robbins (2006), kepuasan kerja adalah cara pekerja merasakan mengenai pekerjaaanya. Kepuasan kerja dipengaruhi oleh beberapa aspek pekerjaan, meliputi: upah/gaji, promosi, rekan kerja, kepuasan terhadap pengawasan dan kepuasan terhadap pekerjaan itu sendiri. Kepuasan kerja merupakan suatu sikap yang positif yang menyangkut penyesuaian diri yang sehat dari para karyawan terhadap kondisi dan situasi kerja, termasuk didalamnya masalah upah, kondisi sosial, kondisi fisik 
dan kondisi psikologis. Kepuasan kerja pada dasarnya merupakan hal yang bersifat individual, setiap individual memiliki tingkat kepuasan kerja yang berbeda-beda sesuai dengan keinginan dan sistem nilai yang dianutnya (Handoko, 2002).

Semakin banyak aspek dalam pekerjaannya yang sesuai dengan keinginan dan sistem nilai yang dianut individu, semakin tinggi tingkat kepuasan yang didapat. Kurang terpenuhinya kepuasan kerja akan menimbulkan penurunan produktivitas karyawan, sehingga pemberian kebutuhan yang bersifat material dan non material perlu diberikan untuk tercapainya kepuasan kerja. Hasil penelitian sesuai dengan penelitian Khan (2011), yang menemukan bahwa adanya pengaruh yang signifikan antara kepuasan kerja dan kinerja. Hasil penelitian juga mendukung penelitian Brahmasari dan Suprayetno (2008), dan penelitian Prabowo dkk (2017) yang secara konsisten membuktikan bahwa kepuasan kerja karyawan berpengaruh positif dan signifikan terhadap kinerja organisasi, artinya bahwa secara umum kepuasan kerja karyawan yang tinggi akan mampu meningkatkan kinerja organisasi.

\section{Pengaruh Motivasi Kerja Terhadap}

Kinerja Karyawan Dimediasi

\section{Kepuasan Kerja}

Hasil pengujian menunjukkan bahwa koefisien pengaruh tidak langsung motivasi kerja terhadap kinerja karyawan melalui kepuasan kerja sebesar 0,168 $(p=0,029<0,05)$ yang berarti kepuasan kerja secara signifikan sebagai variabel mediasi atas hubungan antara motivasi kerja dengan kinerja karyawan. Artinya ketika karyawan yang memiliki kepuasan

\section{KESIMPULAN DAN SARAN}

Berdasarkan hasil penelitian seperti yang telah diuraikan pada bab sebelumnya dapat ditarik beberapa kesimpulan bahwa Motivasi kerja berpengaruh signifikan positif terhadap kepuasan kerja, Kepuasan kerja berpengaruh signifikan positif kerja yang tinggi menyebabkan motivasi kerja karyawan meningkat dan mempengaruhi peningkatan kinerja karyawan PT. Telkom Kantor Wilayah Telekomuniasi Riau Kepulauan - Batam. Dengan demikian hipotesis keempat yang menyatakan "H3: Pengaruh Motivasi Terhadap Kinerja Karyawan Dengan Kepuasan Kerja Sebagai Variabel Intervening Pada PT. Telkom Kantor Wilayah Telekomuniasi Riau Kepulauan - Batam" dapat didukung.

Karyawan memegang peran utama dalam menjalankan roda kehidupan perusahaan. Apabila karyawan memiliki produktifitas dan motivasi yang tinggi, maka laju roda pun akan berjalan dengan kencang. Dengan lajunya roda tersebut, akhirnya akan menghasilkan pencapaian yang baik bagi perusahaan. Dengan adanya motivasi manusia bekerja untuk memenuhi kebutuhan yang dipenuhinya. Tanpa adanya tuntutan untuk memenuhi kebutuhan tidak akan ada aktivitas manusia dalam bentuk kerja untuk menghasilkan suatu kinerja. Bekerja merupakan suatu bentuk aktivitas yang bertujuan mendapatkan kepuasan. Kepuasan tersebut merupakan perpaduan dari hasil usaha dan keinginan karyawan. Berdasarkan usaha dan keinginan tersebut dalam hal ini merupakan motivasi bagi karyawan yang berpengaruh terhadap kinerja karyawan yang ditampilkan dalam pekerjaannya.

Hasil penelitian sesuai dengan penelitian sebelumnya yang menyatakan bahwa kepuasan kerja telah terbukti memiliki peran intervening dalam hubungan antara motivasi terhadap kinerja (Nitasari, 2012).

terhadap kinerja karyawan, Motivasi kerja berpengaruh positif dan signifikan terhadap kinerja karyawan dan Motivasi kerja berpengaruh positif dan signifikan terhadap kinerja karyawan yang dimediasi oleh kepuasan kerja karyawan PT. Telkom 
Kantor Wilayah Telekomuniasi Riau Kepulauan - Batam.

\section{Implikasi Penelitian}

\section{Implikasi Praktis}

Pihak PT. Telkom Kantor Wilayah Telekomuniasi Riau Kepulauan - Batam perlu meningkatkan motivasi kerja karyawan terutama pada indikator kebutuhan afiliasi yaitu dengan memberikan dukungan penuh kepada setiap karyawan, dalam menjalankan tugas-tugasnya serta membangun budaya kerjasama tim, sehingga ada kerjasama yang baik diantara karyawan yang saling menghormati dan menghargai. Setiap karyawan PT. Telkom Kantor Wilayah Telekomuniasi Riau Kepulauan - Batam juga didorong untuk membangun sinergi menuju tujuan bersama, memiliki inisiatif dalam bersikap melayani dan mencari cara-cara baru menyelesaikan berbagai persoalan.

2. Implikasi untuk penelitian yang akan datang

Untuk itu peneliti selanjutnya dapat mengembangkan model penelitian ini, dengan menambahkan variabel lain seperti iklim organisasi, kepemimpinan, budaya organisasi atau lainnya sehingga diharapkan akan memperoleh model yang paling tepat.

\section{DAFTAR PUSTAKA}

Ali, Akbar, Maira A., Jahanzaib H. (2012). Impact of Motivation on the Working Performance of Employees - A Case Study of Pakistan. Global Advanced Research Journal of Management and Business Studies, Vol. 1(4), pp. 126 - 133.

As'ad, Mohammad. (2005). Manajemen Sumber Daya Manusia. Yogyakarta : Galia Indonesia.

Baron, R. M. and Kenny, D. A. (1986). The Moderator-Mediator Variable Distinction in Social Psychological Research: Conceptual, Strategic, and Statistical Considerations.Journal of Personality and Social Psychology, 51(6), 1173-1182.

Brahmasari, Ida Ayu dan Agus Suprayetno. (2008). Pengaruh Motivasi Kerja, Kepemimpinan, dan Budaya Organisasi Terhadap Kepuasan Kerja Karyawan serta Dampaknya pada Kinerja Perusahaan (Studi kasus pada PT. Pei Hei International Wiratama Indonesia). Jurnal Manajemen danKewirausahaan. Vol. 10, September: 124135 .

Dessler, Gary. (2000). Manajemen Sumber Daya Manusia, Edisi Terjemahan. Jakarta : PT. Prenhallindo.

Donni Junni Priansa. (2014) .Perencanaan \& Pengembangan SDM. Bandung: Alfabeta.

Handoko, T. Hani. (2002). Manajemen Personalia Sumber Daya Manusia. Yogyakarta : BPFE.

Hasibuan, Malayu S.P. (2009). Manajemen: Dasar, Pengertian dan Masalah Edisi Revisi. Jakarta : Bumi Aksara.

Innayatullah, Atiya dan Jehangir Palwasha. (2013). Teacher's Job Performance: The Role of Motivation.Abasyn Journal of Social Science. Vol.5. pp. 78 - 99. 
Jehanzeb, Khawaja, Rasheed M. F., Rasheed A. dan Aamir A. (2012). Impact of Rewards and Motivation on Job Satisfaction in Banking Sector of Saudi Arabia.International Journal of Business and Social Science. Vol. 3, No. 21. pp. 272 - 278.

Khan, Alamdar H., Muhammad Musarrat N., Muhammad Aleem dan Wasim H. (2011). Impact of job satisfaction on employee performance: An empirical study of autonomous Medical Institutions of Pakistan. African Journal of Business Management. Vol. 6 (7), pp. 2697 - 2705.

L. Mathis, Robert - H. Jackson, John. (2011). Human Resource Management, Edisi Sepuluh. Jakarta:Salemba Empat

Luthans, Fred. (2009). Organizational Behavior Tenth Edition. Singapore: McGraw - Hill Book.

Miao, C Fred dan R, Evans Kenneth. (2007). The Impact Of Salesperson Motivation On Role Perceptions and Job Performance - A Cognitive and Affective Perspective.Journal of Personal Selling and Sales Management. Vol. 27. pp. 89 - 101.

Moeheriono. (2010). Pengukuran Kinerja Berbasis Kompetensi. Bogor: Ghalia Indonesia.

Mutmainah, Wijayanti. (2012). Pengaruh Penerapan Corporate Governance Terhadap Kinerja Keuangan Pada Perusahaan Perbankan Yang Terdaftar Di Bursa Efek Indonesia. Diponegoro Journal Of Accounting Valume 1 Nomor 2.

Nitasari, Rizka Afrisalia. (2012). Analisis Pengaruh Motivasi Kerja Terhadap Kinerja Karyawan Dengan Kepuasan Kerja Sebagai Variabel Intervening Pada PT. Bank Central Asia Tbk. Cabang Kudus. DiponegoroJournal of Management, Vol.1, No.2. hal. 446 - 454.

Rivai, Veithzal. (2008). Manajemen Sumber Daya Manusia untuk Perusahaan dari Teori ke Praktik. Jakarta: PT Raja Grafindo Persada.

Robbins, S. P. (2006). Perilaku Organisasi. Jakarta: Salemba Empat.

Robbins, S.P. dan Judge T.A. (2008). Perilaku Organisasi. Buku 2. Jakarta: Salemba Empat.

Sugiyono. (2013). Metode Penelitian Pendidikan : Pendekatan Kuantitatif, Kualitatif dan RdanD. Bandung: Alfabeta.

Tentama, F. (2015). Peran Kepuasan Kerja Terhadap Kinerja Pada Guru Pegawai Negeri Sipil (PNS) Di Yogyakarta.Jurnal Psikologi Undip Vol.14 No.1. Hal 1 - 8.

Wardhana, Aditya. (2014). Manajemen Sumber Daya Manusia. Bandung: Karyamatunggal Lithomas.

Wibowo, Edi dan Susilowati. (2010). Pengaruh Kepemimpinan, Organizational Citizenship Behaviour dan Komitmen Organisasional Terhadap Kepuasan Kerja Pegawai.Jurnal Ekonomi dan Kewirausahaan, Vol. 10, No. 1. pp. 66 - 73. 


\section{Buletin Ekonomi}

Yousaf, A., Yang Huadong, Sanders Karin. (2015). Effects of Instrinsic and Extrinsic Motivation on Task and Contextual Performance of Pakistani Professionals.Journal of Managerial Psychology, Vol. 30. pp. 133 - 150.

Zameer, Hashim; Ali,Shehzad; Nizar, Waqar; Amir,Muhammad. (2014). The Impact of the Motivation on the Employee's Performance in Beverage Industry of Pakistan.International Journal of Academic Research in Accounting, Finance and management Sciences, Vol. 4. pp. 293 - 298. 